than the eastern. "If the orbit had remained unchanged from 1877 , the western distance in 1894 should have been about $\mathbf{I}^{\prime \prime} \cdot 8$ greater than the eastern. The change of nearly $2^{\prime \prime} \cdot 8$ was evidence of a marked transformation of the orbit during the years 1877-94. The line of apsides has probably revolved owing to a polar compression of the planet." The observations also appear to indicate a similar transformation of the orbit of Deimos, but the evidence is not quite so conclusive.

Both satellites are about 6 minutes behind Marth's ephemeris, so that the adopted values of their periodic times require slight correction.

ECLIPSE OF THE MOON, MARCH Ir.-The following particulars with regard to the total eclipse of the moon on the morning of Monday, March II, may be of interest:-

\begin{tabular}{|c|c|c|c|c|c|c|}
\hline \multirow{2}{*}{\multicolumn{3}{|c|}{ First contact with penumbra }} & \multicolumn{4}{|c|}{ G. M. T. } \\
\hline & & & $\cdots$ & $\cdots$ & $\cdots$ & \\
\hline \multicolumn{3}{|c|}{ Beginning of total phase } & $\cdots$ & $\begin{array}{l}\ldots \\
\ldots\end{array}$ & $\cdots$ & $\begin{array}{l}153^{\circ} \\
251^{\circ}\end{array}$ \\
\hline Middle &, & , & . & $\cdots$ & $\cdots$ & $339^{\circ}$ \\
\hline End & & , & $\cdots$ & $\cdots$ & $\cdots$ & 426 \\
\hline \multicolumn{3}{|c|}{ Last contact with shadow } & $\cdots$ & $\cdots$ & $\cdots$ & $524^{\circ}$ \\
\hline ", &, & nenum & $\cdots$ & $\cdots$ & $\cdots$ & 6 \\
\hline
\end{tabular}

The first contact with the shadow will occur at $127^{\circ}$ from the north pint of the moon's limb towards the east, and the last contact at $69^{\circ}$ towards the west, in both cases for the direct image as seen with the naked eye. The magnitude of the eclipse (moon's diameter $=$ unity) will be $r^{*} 6$ I 9 .

The moon will be seen in the shadow at places between longitudes $5 \mathrm{~h}$. E. and $\mathbf{I} \mathrm{h}$. W. Among the principal stars occulted during the eclipse will be 83 Leonis, mag. 75 , which will disappear at $2 \mathrm{~h}$. $17 \mathrm{~m}$. at an angle of $95^{\circ}$ and reappear at $3 \mathrm{~b}$. $12 \mathrm{~m}$. at an angle of $33^{\circ}$; and $\tau$ Leonis, mag. $5^{\circ} \mathrm{O}$, which will disappear at $2 \mathrm{~h}$. $56 \mathrm{~m}$. at $86^{\circ}$, and reappear at $3 \mathrm{~h}$. $43 \mathrm{~m}$. at an angle of $345^{\circ}$; the angles being reckoned from north towards east.

\section{THE NILE.}

I AM to speak to you to-night of the Nile, and I think I may fairly say it is the most famous river in all the world famous through all the ages, for the civilisation that has existed on its banks; famous for its mystic fabulous rise, about which so many sages and philosophers have pondered; famous for its length, traversing one-fifth the distance from pole to pole; famous, and apparently destined to be famous, for the political combinations that ever centres around it. But I feel I must begin by an apology, for now that Egypt has come so com. pletely within the tourist's range, probably many of my hearers have seen more of the Nile than I have.

If a foreigner were to lecture to his countrymen about the river Thames, and were to begin by informing them that he had never been above Greenwich, he might be looked upon as an impostor; and perhaps I am not much better, for I have never been higher up the river than Philæ, 6 ro miles above Cairo. For information regarding anything higher up, I must go, like you, to the works of Speke, Baker, Stanley, and our other great explorers. I shall not, then, detain you to-night with any elaborate account of this upper portion of the river, but will only remind you briefly of that great inland sea, the Victoria Nyanza, in extent only a little less than the American Lake Superior, traversed by the equator, and fed by many rivers, some of them taking their rise as far as $5^{\circ} \mathrm{S}$. Iat. These rivers form the true source of the Nile, the mystery only solved in the present generation.

The outlet of this great lake is on its north shore, where the river rushes over the Ripon Falls, estimated by Speke at only 400 or 500 feet wide, and with a drop of 12 feet. Thence the river's course is in a north-west direction for 270 miles, to where it thunders over the Murchison Falls, a cliff of 120 feet high. Soon after that it joins the northern end of Baker's Lake, the Albert Nyanza, but only to leave it again, and to pursue its course through a great marshy land for more than 600 miles, to where the Bahr Gazelle joins it from the west; a little further down the great Saubat tributary comes in on the east. This is the region in which the river is obstructed hy islands of flnating vegetation which, if checked in their course, at last block up its whole width, and form solid obstructions known as sadds, subsiantial enough to be used as bridges, and obstacles, of cuurse, to navigation, until they are cleared away. The waters of the Saubat are of very light colour, and tinge the whole river, which, above its junction, is green and unwholesome, from the long chain of marshes which it traverses. Hence it is called the White Nile. 600 miles further brings us to Kharıoum, where the Blue Nile from the Abyssinian mountains joins it, and at 200 miles still further to the north it is joined by the Atbara river, also from Abyssinia, a torrent ralher than a river.

Baker gives a graphic account of how he was encamped by the dry bed of the Athara on June 22, 1861. The heat was intense, the country was parched with drought. During the night the cry went forth that the floods were coming, and in the morning he found himself on the banks of a river, he says, 500 yards wide and from 15 to 20 feet deep. All nature had sprung into life. A litıle north of the junction of the A bara is Herber, whence you will remember is the short cut to Suakin in the Ked Sea, which so many thought woull have been the trie route for our Army to take in relieving Gordon. From Khartoum to Assouan is a distance of 100 miles of river, during which it makes two immense curves, for on a straight line the distance is not half so much, and it is in this part of its course that $i$ parses over the six great cataracts or rapids which hlock all ordinary navigation. The first or furthest north cataract is just above Assouan, a dis'ance of 750 miles from the Mediter ranean, through the country known as Egypt. From the junction of the A bara to its mouth in the Mediterranean, a distance of 1680 mile;, the Nile receives no tributary. On the contrary, duri g every mile of is course its waters are diminished hy evaporation, by ahsorpti $\mathrm{n}$, and by irrigarion. The river gets less and less as it flows throunh this rainless land, and its maximum volume is to be found during the flosds at the junction of the Albara, and at other seasons at Khartoum, 1875 miles from the Mediter. ranean.

The whole distance by river from the Victoria Nyanza to the sea is about 3500 miles. It may not be easy to derive any clear impression from this hare recital of mileage. Let me try to convey to you in some other ways the idea of the length of the Nile. Standing on the bridge at Cairo, I used to reflect that I was just about half-way between the source of the Nile and the White Sea. Or to put it another way: if we could suppose a river crossing our English Channel, and that the Thames should find its outlet in the Euphrates and the Persian Gulf, that river would be about as long as the Nile.

In this short sketch of the course of the Nile, I must not forget to mention one interesting feature. About 40 miles south of Cairo, the low Lihyan chain of hills which bounds the Nile valley on the west is broken by a gap, through which the waters of the river can flow, and beyond this gap lies a saucershaped depression called the Fayúm, of about 400 :quare miles in area, sloping down to a lake of considerable size, the surface of whose waters stands about 130 feet below that of the sea. This lake is known as the Birket el Kurún.

From the time of the earliest Egyptian records, this province of the Fayum was famed for its fertility, and to the Egyptian taste for its delightful climate. Many of the most precious monuments of antiquity have been found in the Fayum. The famous Labyrinth is supposed to have stood just at its entrance; and what has excited most interest for the engineer in all times, it is here that Herodotus places that wonderful lake Mœris, which receiving for half the year the surplus supply of the Nile, rendered it back again in irrigation to Lower Egypt during the other half. Where this lake actually was, has excited discussion since any attention has been paid to ancient Egyptian history. It seems pretty clear that in earlier days the Birket el Kurún was of much greater proportions than it is now, but how it ever could have been large enough to allow of its waters fl'swing back into the Nile valley when the river was low, wilhout at the same time drowning the whole Fayum, is not very clear.

Now, what are the functions of a great river, what are the offices which it renders to man? And first of all, at least in this latitude, we would mention the carrying off to the ocean of the surplus water that descends from the skies. Nobly does the Nile fulfil this duty; but with this enormous qualification, that it transports the water from tracts where there is too much, and carries it all free of cost, not to waste it in the sea, but to 
bestow it on tracts where it is of priceless value, more than taking the place of rain in watering the fields.

The next functi in of a river is to f rm a highway through the land, and for most of it: course the Nile fulfils this duty well too. Gordon considered it possible for steamers to ascend the Nile during the flood: from its mouth to the Fola ra idi, a distance of about 3040 miles; hut at other seasons, the six cataracts cannot be passed. Leaving out the 1100 miles which they occupy, there is an unbroken 750 miles in the lower, and nearly 1200 miles in the upper river. I cannot look on it as probable that it will ever pay to make navigable canals and locks round these cataracts, as it would entail so much hard rock-cutting.

Another function of a river is to promote industry by the employment of its water-power. We know how valuable is this power even in England, and how much more in countries like Switzerland, where it abounds. and on the great livers of America. Excepting a few very rude wooden wheels in the Fayún, I do not know, through all the annals of the past, of a single water-wheel ever turned by the power of the Nile. But that power exists to an almost unlimited extent. And may we not prophesy that some day in the future, when that long stretch of Nubian cataracts has fallen into civilised hands, and when we know how to transmit electric energy with economy, that then our descendants will draw wealth to Egypt from its chain of barren cataracts?

As a drainage outlet to a continent, as a long highway, as a source of power, the Nile is great; but not so much so as many other rivers. Its unique position is due to the benefit it confers on Egypt in turning it from being a desert into being the richest of agricul'ural lands, supporting with ease a population of about six hundred to the square mile. Herodotus truly said Egypt is the gift of the Nile. It more than supplies the absence of rain, and this it does, first, by the extraordinary regularity with which it rises and falls; and secondly, by the fertilising matter which the waters carry in suspension, and bestow upnn the land. Imagine what it would be to the English farmer if he knew exactly when it would rain and when it would be sunshine. When the I rigation Department of Egypt is properly administered, the Egyptian farmer possesses this certainty, and he has this further advantage- that it is not merely water that is poured over his lands, but, during nearly half the year, water charged with the finest $m$ inure.

According to the early legend, the rise of the Nile is due to the tears shed by Isis over the tomb of Osiris, and the texts on the Pyramids allude to the night every year on which these tear-drops fall. The worship of Isis and Osiris has long passed away, hut to this day every native of Egypt knows the Lailet en Nuktah, the night in which a miraculous drop falls into the river, and causes it to rise. It is the night of June I7. Herodotus makes no allusion to this legend of Osiris. In his time, he says, the Greeks gave three reasons for the river's rise. He believed in none of them, but considered, as the most ridiculous of all, that which ascribed the floods to the melting of snows, as if there cisuld possibly be snows in such a hot region. It was many centuries after Herodotus' time when the snowy mountains of Central Africa were discovered.

The heavy rains commence in the basin of the White Nile during April, and first slowly drive down upon Egypt the green stagnant waters of that marshy region. These appear at Cairo about June 15. About a fortnight later the real flood begins, for the rains have set in in Abyssinia by May 15 , and the Blue Nile brings down from the mountains its supply of the richest muddy water. It is something of the colour and nearly of the consistency of chocolate, and the rise is very rapid, as much sometimes as 3 feet per diem, for the Athara torrent having saturated its great sandy bed, is now in full flood also. The maximum flood is reached at Assouan about September I, and it would reach Cairo some four days later, were it not that during August and Sep ember the water is being diverted on to the land, and the whole Nile valley becomes a great lake. For this reason the maximum arrives at Cairo about the beginning of October. The rains cease in Abyssinia about the middle of September, and the floods of the Blue Nile and Atbara rapidly decrease; but in the meantime the great lakes and marshes are replenished in the upper regions, and slowly give off their supplies, on which the river subsists, until the following June. Yearly this phenomenon presents itself in Egypt, and with the most marvellous regularity. A late rise is not more than about three weeks later than an early rise. In average years the height of the flood at Assouan is about $25^{\frac{1}{2}}$ feet above the minimum supply. If it rises 29 feet above this minimum, it means peril to the whole of Egypt, and the irrigation engineer has a hard time of it for two months. If the river only rises 20 feet ahove the minimum, it means that whole tracts of the valley will never be submerged. Such a poor flood has happened only once in modern times, in 1877 , and the result was more serious than the devastation caused by the most violent excess.

The mean flood discharge at Cairo is about 280,000 cubic feet per second, the maximum about 400,000 . The mean lowest Nile is about 14,000 cubic feet per second at Cairo, but some years there is not more than 10,000 cubic feet per second pa-sing Cairo in June, and within three months after this may have increased forty.fold.

Until this century, the irrigation of Egypt only employed the flood waters of the river, and it was this that made it the granary of the world. No doubt, rude machines for raising Nile water were used at all seasons and from all times. But by these it was not possible to irrigate on a large scale, and in reality they were only employed for irrigating vegetables or gardens, or other small patches of land. It must not be thought that the water of the flooded river is ever allowed to flow where it lists over the lands. The general slope of the valley on each side is away from the river, a feature which the Nile shares with all Deltaic streams. Along each edge of the river, and following its course, is an earthen embank. ment, high enough not to be topped by the highest flood. In Upper Egypt, the valley of which seldom exceeds six miles in width, a series of embankments have been thrown up, abutting on their inner ends against those along the river's edge, and on their outer ends on the ascending sides of the valley. The whole country is thus divided into a series of oblongs, surrounded by embankments on three sides, and by the slope of the desert hills on the fourth. In Lower Egypt, where in ancient days there were several branches of the river, this system was somewhat modified, but was in principle the same. These oblong areas vary in extent from 60,000 to 3000 or 4000 acres, and the slope being away from the river, it is easy to cut short, deep canals in the banks, which fill as the flood rises, and carry the precious mud-charged water into these great flats, or, as they are termed, basins of irrigation. There the water remains for a month or more, some three or four feet deep, de. positing its mud, and then at the end of the flood it may either be run off direct into the receding river, or, more usually, passed off through sluices from one basin to another, and ultimately back into the river. In November the waters have passed off, and wherever a man and a pair of bullocks can walk over the mud, and scratch its surface with a wooden plough, or even the branch of a tree, wheat or barley is sown, and so saturated is the soil that the grain sprouts and ripens in April or May without a drop of rain or any fresh irrigation. And a fine crop is reaped. One of our great brewers told me the other day, that when barley grown in this country was spread in the malting-house, about three per cent of it must be counted on as not sprouting and being dead. If grain two or three years old was used, as much as twenty per cent. would be found dead. With Egyptian barley, he said, even after several years, you could count on every grain germinating. The crop once reaped, the fields remain dry, and crack in the frerce summer heat until next flood comes on.

The tourist who only comes to Egypt to shun "winter and foul weather," knows nothing of the majestic glories of the Nile flood. The ancient Nilometer at the south end of the island of Roda, just above Cairo, is one of the most interesting sights of the place. The water enters from the river by a culvert into a well about 18 feet square, with a graduated stone pillar in the centre. On each side of the well is a recess about 6 feet wide and 3 feet deep, surmounted by a pointed arch, over which is carved in relief a Kufic inscription, and a similar inscription is carried all round the well, consisting of verses of the Koran. A staircase goes down the well, from the steps of which the initiated may read the height of the water on the pillar; but they ale few in number, and the hereditary Sheikh of the Nilometer, whose duty it is to keep the record, is a person of some importance. The Nilometer dates from A.D. $86 \mathrm{I}$, and I believe in the archives of Cairo may be found the daily record for 1000 years.

I need hardly tell you that when our English engineers took the river in hand, we established a number of gauges at Wadi Halfa, Assouan, Cairo, and many other points, on more scientific principles than the venerable Nilometer of the Roda Island.

After the river has begun to rise, its height is daily chanted 
through the Cairo streets until it reaches 16 cubits on the gauge. At this point the Khalig el Masri, the old canal that flows through the heart of Cairo, is opened-up to this point it is dry, and full or empty it is little more than a sanitary abomination at present ; but in former days it occupied an important place, and when the Nile water was high enough to flow down its bed, it was looked on that the flood had fairly set in, and that the kindly fruits of the earth might be duly expected.

The head of this canal is on the right bank of the river, just south of Cairo. The water enters a channel some 30 feet wide, with a high wall on its left, and a sloping bank on its right or southern flank. The water then flows under the pointed arch of an old stone bridge. The bed of the canal is cleared so that it would flow in at a gauge of about $14 \frac{1}{2}$ cubits, but an earthen bank is thrown acros; it about 4 feet higher.

There is no more interesting ceremony in Egypt than the annual cutting of the Khalig, as the opening ceremony is called. It takes place between August 5 and 15 . Days before preparations are being made for the festival. Tents with innumerable lamps are placed along the wall on the one side. Frames for all manner of fireworks are erected on the sand-bank on the other side. All the notables are there in full uniform, or in canonicals. The Khedive himself, or his representative, the Sheikh ul Islam (the highest dignitary of the Muhammedan faith), the Sheikh el Bekri, the Sheikh es Sadat, all the learned scribes of the great university of the Azhár, the Cabinet Ministers and Under-Secretaries, the Sirder of the Army and his staff, the Judge; and the Financiers.

The Egyptian troops are turned out, salutes are fired, and about eight o'clock in the warm summer night the classes all assemble under the gaily.lighted tents, the masses crowd round the frames for the fireworks, the street is lined with harem carriages full of closely-veiled figures, though it is not much that they can see from their broughams. Out in the river, just opposite the canal's mouth, is moored an old hulk of a certain sea-going outline, which has been towed up from Boulak during the day, and is an emblem of the time when the great republic of Venice sent an envoy to witness the ceremony. This boat is full of lamps, and fireworks too. As the night deepens the excitement increases. The populace on the bridge and the opposite bank are shouting, yelling, and dancing wildly round the fireworks. On the oither side are the gay uniforms and lighted tents, from whence we can look over the wall down on the dark water, where you see brown figures plunging in and waistdeep digging with their hoes at the embankment that blocks the canal's mouth.

Long before midnight the fireworks have gone out, and left the splendid stars to themselves; the grandees have all gone to bed, but the people keep up the revelry, and in the morning, by 7.30 , every one has come back. Then but little of the bank is left uncut; a few more strokes of the big hoes will do it, and the brown skins and the brown water reflect the bright sunlight from above. Then the Sheikh ul Islam solemnly thanks the Almighty, Allah the All-powerful, the All-merciful. He im. implores His blessing on the flood, and at a signal the bank is cut, the waters rush in, and with them a crowd of swimmers. A bag of silver piastres is scattered among them, and the ceremony is at an end.

There is a pretty legend, worth telling, of the cutting of the Khalig. Amr, the Muhammedan General, took Cairo in A.D. 640. Long before then there had been a heathen ceremony, and a virgin was yearly sacrficed to the god of the river. When the season came round, Amr was called upon as usual to sacrifice the girl. He sternly refused. That year the Nile flood was a failure. You can fancy how the indignant heathen population must have raged at the invader, and said, "We warned you what would happen if you didn't propitiate the river god." Cannot we fancy, also, how Amr's wild Arab soldiers must have had their faith sorely tried, and how they must have felt puzzled as to whether in this strange new country, with all those demonbuilt temples and pyramids, obelisks and sphinxes, it might not be as well to make friends of the local gods. Could Allah really help them here? Again the Nile flood came round. This time surely Amr would sacrifice the girl, and save the land. No; he would not. The people rose in rebellion. Amr stood firm. But he wrote to the Kalif Omar for orders (Omar, whose name you will remember has come down in history as the destroyer of the Alexandrian library). Omar approved of his conduct, but sent him a paper to throw into the Nile. On the paper was written, "From Abd Allah Omar, Prince of the
Faithful, to the Nile of Egypt. If thou flow of thine own accord, flow not; but if it be Allah, the one the mighty, who causeth thee to flow, then we implore him to make thee flow." Amr threw the paper into the water, and the Nile rose forthwith exactly as it was wanted. Since that day no girl has been sacrificed; but a pillar of earth is yearly left to be washed away in the middle of the canal, called the bride or the girl.

Such, as I have briefly described it, was the irrigation of Egypt until this century, when it fell under the rule of Muhammed Ali, a very sagacious and strong if a very unscrupulous ruler. $\mathrm{He}$ saw that the country could produce far more valuable crops than cereals. The European market could be supplied with these from the fields of Europe, but Europe could not produce cotton and sugar-cane. Egypt had the climate, had the soil, had the teeming population; but these crops required water at all seasons; nor would it do to flood the fields to any depth, for just at the flood season the cotton crop is ripening. There was plenty of water in the river; but how was it to be got on to the land? Perennial irrigation was a fresh departure. As I have said, the Nile rises about $25 \frac{1}{2}$ feet. A canal then running I 2 feet deep in flood has its bed $3^{\frac{1}{2}}$ feet above the surface of the Low Nile. Either the Nile water had to be raised, or the beds of the canals had to be lowered, in order that one should flow into the other, and after that the water had to be raised from the canal on to the land. Muhammed Ali began by lowering the canal beds of Lower Egypt, an enormous work considering the great number of the canals; and as they had been laid out on no scientific principles, but merely to suit the fancies of Turkish pashas or village sheikhs, and as those who had to excavate them to this great depth had only the slightest knowledge of levelling, the inevitable result followed-the deep channel became full of mud during the flood, and all the excavation had to be done over again. Incredible as it may seem, this great work was done year after year. It was a great serf population; if they were not fighting Muhammed Ali's battles in Arabia and Syria, they might as well be digging out the canals. No one thought of paying or feeding the workmen. The bastinado was freely applied if they attempted to run away. If they died under the labour, there were plenty more to come. But of course the work was badly done. The water might enter the canal; but as the bed was not truly levelled, it did not follow that it would flow far. Then, as the river daily fell, the water in the canals fell too, and lessened in volume as the heat increased, and more was required. At last-in June, perhaps - the canal was dry, and the cotton crop that had been sown and watered, weeded and nurtured, since March, was lost altogether.

Then some one advised Muhammed Ali to throw a dam across the river, and so raise the water, and the result was the great Barrage.

About twelve miles north of Cairo the Nile bifurcates, and finds its way to the sea, by the Rosetta and Damietta branches. Across the heads of these two branches were built two stone bridges, one of $7 \mathrm{I}$, the other of $6 \mathrm{r}$ arches, each 5 metres or 16.4 feet span. These arches were intended to be fitted with gates ; by lowering which, all the water would be dammed up, and diverted into three great trunk canals, taken out of the river just above these bridges. One to the right or east of the Damietta branch was to supply wattr to all the Provinces of the Eastern delta, one between the two bridges was to supply the splendidly fertile central delta, the third to the left or West of the Rosetta branch was to water all the Western delta down to Alexandria.

There was no intention of water storage at the Barrage, but it was merely with the object of controlling the supply. While there was water enough in the river, by closing the gates it could be kept to a uniform level, and sent down the three trunk canals, from which it was to branch, into many minor ones. As the river went down, gate after gate would be closed, and so a constant supply could be kept in the canals. The idea was thoroughly sound. The execution was feeble.

Mougel Bey, the French engineer in charge of the work, had no doubt many difficulties to contend with. The work went fitfully on for many years, thousands of men being forced to it one year, and carried off to a campaign the next. But at last it was sufficiently finished to allow of an opening ceremonial in 186r. Gates had been fitted into the Rosetta branch arches, never into the Damietta.

The Central canal had been dug in tolerably satisfactory style. The Western canal, too, had been dug, but passing through a strip

$$
\text { NO. } 1323 \text {, vol. } 517
$$


of desert it had become very much filled up with sand. The Eastern canal was dug some five miles, and then stopped. Of course the Rarrage without these canals was useless. However, they began to experiment with it, closing the gates on the Rosetta side. It was intended to hold up $4 \frac{1}{2}$ metres, or I 4 feet 9 inches of water. It never held up 5 feet, till in I867, it cracked across from top to bottom, on the Western side. An immense cofferdam was built round the cracked portion, and the water was never held up again more than about $3 \frac{1}{2}$ feet, while the work was looked on as a deplorable failure. In $\mathrm{r} 883$, all hope of making anything out of the Barrage was abandoned, and the Government were on the point of concluding a contract with a company to supply Lower Egypt with irrigation by means of an immense system of steam pumps, to cost $£ 700,000$ to begin with, and $£ 250,000$ a year afterwards.

That year there was a wretched serf army of 85,000 men working at canal clearances for 160 days, unfed, unpaid. The burden was nearly intolerable. The irrigation was all by fits and starts. There was no drainage ; every hollow became sour and water-logged. With waterways everywhere, there was no navigation. In Upper Egypt things were better, as the system was a simpler one. But when we came to look into them ton, we found great abuse, and on an average about 40,000 acres never succeeded in obtaining water, though in the midst of abundance.

The Fayum had long been a much-neglected province, though a most picturesque and attractive one. From carelessly allowing Nile water to flow into the lake during the floods, it had risen enough to swamp 10,000 acres of valuable land, and this mischief we found still increasing.

Throughout the whole country drainage had been absolutely neglected. And here I would point out that irrigation without drainage means the sure deterioration of the land sooner or later. Considerable pains had been taken in Egypt to get the water on to the land. No sort of effort had been made to get it off. In a properly irrigated tract, between every two canals of supply, there should flow a drainage channel; the former should follow as far as possible the highest lands, the latter should follow the lowest. The canal gets smaller, till at last it is exhausted, giving itself out in innumerable branches. The drain, like a river, gets larger as it proceeds, being constantly joined by branches. But if there be nodrains, and if the canals are laid out to flow into one another, so as to divide the country into, as it were, a cluster of islands, you can understand how the drainage water has no means of flowing off into the sea, and settles in unwholesome swamps. These we found prevailing to an alarming extent in the rich provinces of the delta. Such was the wretched state of Egyptian agriculture-the one single source of the country's wealih-when Lord Dufferin laid down the lines of the English administration, which have been amplified and pursued ever since.

It was in May, 1883 , that I took charge of the irrigation department in Egypt, having before then had some twenty years' experience of similar work in India ; and I soon had the inestimable advantage of being joined by a band of the most indefatigable, energetic and able engineers, also from India, with whom it was my great privilege and happiness to be associated for the next nine years. I cannot talk too highly of these my colleagues-men who knew their work and did it, who kept constantly moving about in the provinces, badly lodged, badly fed, denied domestic comforts, constantly absent from their wives and families (they were all married men).

My friends, happy is the reformer who finds things so bad that he cannot make a movement without making an improvement. Happy the reformer who has as colleagues a staff of thoroughly loyal, duty-äoing and capable men. Happy the reformer who is not pestered on all sides by the officious advice of the ignorant. Happy the reformer who has behind him a strong brave chief, as honest and truthful as he is strong. Such rare happiness fell to me in Egypt with my noble colleagues, and with Lord Cromer as our chief.

It is not my intention to enter into any details to-night of what our work was in Egypt. I have lately spoken about that elsewhere, and there would be no time to do so now. I must just describe it generally.

On first arrival, I was pressed, both by English and French men, to go into the question of the storage of the flood waters of the river on a large scale. I declined to do so, considering it would be time enough to think of increasing the quantity of water at our disposal when we had profitably used all that we already had, and while mighty volumes were daily flowing out to the sea, it could not be said that we were doing that. The first great work to be studied was the Barrage. We were warned on all sides to have nothing to say to it, as it was thoroughly unsound; but we felt sure we must either make it sound or build an entirely new one, and we resolved on the former. The work had failed because it was faulty in design, the floorings and foundations not being sufficiently massive, and faulty in execution from the dishonest use of bad materials and from bad workmanship. The bed of the river consists of nothing more stable than sand and alluvial mud for at least 200 feet deep. It was out of the question to think of getting down to solid rock. It was not, as we thought, very safe to excavate very deeply close to the existing works, so we decided not to try it, but merely to strengthen and consolidate the foundations, built as they were on sand. I have said that the work consisted of two great bridges over the two branches of the river. We could not shut up either branch entirely; but we decided to strengthen and complete one-half of each bridge each season, which meant four seasons' work. While the river was still in considerable flood each November, we began to throw out great embankments of earth about 200 feet from the bridge ; one up-stream, the other down-stream of it, beginning at the shore end, and ultimately enclosing one half of the river as in a pond. This used to take three months' hard work. Then we pumped the water out of this enclosure, and laid bare the very bed of the river. Then we laid a massive stone flooring, $5^{\frac{1}{2}}$ feet thick, extending 100 feet up-stream, and as much down-stream, of the bridge. This was very difficult and hard work. It was kept going day and night, without intermission, from March till the end of June. Then we cut great holes in our embankments, cleared out our machinery, and prepared for the arrival of the flood at the beginning of July. Each year one-half of one bridge was finished, and the whole was completed at the end of June 1890 .

In connection with the Barrage were completed the three great canals to carry off all the river supply from above it. So that practically now the Low Nile is emptied every season at the Barrage and diverted into these canals, and no water at all escapes to the sea. The natives wade everywhere across the river north of this point. Since it was completed the Barrage has given no trouble. It holds up every year 4 metres, or I 3 feet of water. The three trunk canals were all supplied with locks 160 feet by 28 feet, and adapted for navigation. The whole of these works cost about $£ 800,000$. The annual increase of the cotton crop, compared to what it was before 1884 , is never less than two and a half millions sterling, which has not been a bad investment for Egypt.

Turning to Upper Egypt, my colleague, Colonel Ross, directed his attention very closely to the adjustment of canals overlapping one another, passing under and passing over one another; so that in future I trust that with the feeblest Nile flood it will be possible to pour water over every acre of the land.

The question of drainage was very thoroughly taken up. Twelve years ago it may be said that there were no drainage channels in Egypt. Two years ago there were about rooo miles of such channels, some with beds as wide as 60 feet and flowing deep enough to carry cargo boats, others with beds only 3 or 4 feet wide. I am glad to say by these means large tracts in Lower Egypt which had been abandoned as totally ruined have now been restored to cultivation. The level of the lake in the Fayum was reduced by 13 feet between 1885 and 1893 , and most of the inundated lands around it have been again dried.

I have already mentioned the cruel hardship of the corvée, the serf army of 85,000 men who were employed in the canal clearances from lanuary to July, nearly half the year. I believe this institution was as old as the Pharaohs, and it was not easy to abolish it. But of course it went sorely against our British grain Little by little we got money to enable us to pay our labour. By an annual outlay of $£ 400,000$ this spring corvée has entirely ceased since 1889 , and now the Egyptian labourer carries out these clearances in as free a manner as his brother in Middlesex, and gets paid for his work.

Having thus, to the best of our powers, utilised the water in the river flowing past us, we turned our attention to the storage of the surplus waters. Without some such storage it is impossible to increase the cultivation during the Low Nile. All the water is used up. During High Nile there is always a grea volume escaping useless to the sea. 
There are two ways in which the water may be stored ; either by throwing a dam right across the river and forming a great lake above it, or, if such a place can be found, by diverting the flood water into some suitable hollow, and drawing it off from there at the season of low supply, as done by Herodotus' celebrated Lake Mœris. At one time there was a hope that such a storage basin might be found. An American gentleman, named Mr. Cope Whitehouse, in search of the real Mœris, found a very remarkable saucer-shaped de pression just south of the Fayúm. We knew it could not have been Moris, because in its bed we found no traces of a deposit of Nilotic mud, but it might be possible all the same to utilise it. The place was very carefully surveyed, and the project was estimated; but it was found that the cost of conveying the water into this basin would be so great that it was out of the question.

Attention was then turned to the possible sites where a stone dam might be built right across the river. The southern boundary of Egypt just now is near Wady Halfa, the second cataract. It is no use going to look for sites south of this, for the country is in the hands of the Mahdi and his fierce dervish soldiers. North of this point, unquestionably the best site, perhaps the only possible site is where the Nile valley is traversed by a broad dyke of hard Syenite granite, in passing over which the river forms its first cataract just south of Assouan. It is here divided into several channels between rocky islands, and no channel is deep, so that it would be easy to divert the water from one after another, to lay bare the bed of the river, and lay the foundations of the dam in the open air. It wants no engineer to understand what an advantage this is.

And the great dam, such as was designed by Mr. Willcocks, would have been a work worthy of the land of the Pyramids and Karnak-a great wall of squared granite blocks -82 feet thick at base, of a maximum height of 115 feet, $1 \frac{1}{4}$ miles $1 \mathrm{nng}$, pierced by sluices large enough to allow of the whole Nile at highest flood rushing through. The lake formed would have been 120 miles long. Would this not have been a work of some majesty to commemorate for ever the English rule in Egypt-a work one would have been proud to have had a hand in? But it was not to be. The Egyptian saw no objection to it. The money could have been found. But there was an insuperable obstacle created when, on the Island of Philæ, about 250 B.C., Ptolemy II. built a temple to Isis, on the site of older buildings long disappeared. Round this temple other buildings clustered, built by Greeks and Romans. Those of you who have not seen them, are probably familiar from pictures with the group of venerable buildings standing amidst palm trees on the rocky island, and reflected in the waters below.

Had Ptolemy only built his temple on the island of Elephantine, a few miles north, it would have been unaffected by the great dam, but Philæ is just to the south, or up-stream side of where the great dam must necessarily have come, and in consequence the island, with its temples, would be drowned for about six months every year. You probably remember the outburst of rage and indignation which the announcement of this proposed desecration created in London last summer. It was not to be tolerated that England should commit such vandalism. In vain it was answered that the place belonged to Egypt, not to England-that the Egyptian, who was to gain so much by the dam, cared absolutely nothing ahout Ptolemy and his temples-that he was prepared to pay a large price for a great work to benefit his country. What business was it of England to forbid him?

And it was not only the English who were indignant. For once, and only for once, I fear, since we occupied Egypt in 1882. was educated opinion in England and France at one. Both alike insisted that Philæ should not be drowned. Nor must I admit had all the engineers that were interested in the question the full courage of their opinions. While they longed to build the dam, and lamented the perverse fate that had put Philæ there, still they wished to spare Philæ-and their voice has prevailed. The majestic structure has been cut down 27 feet, and now will only be 88 feet high, and Philæ will stand henceforth in a lake, but will never be drowned.

Personally I accept the situation, for I never believed that it would be sacrificed. But yet as an engineer, I must sigh over the lost opportunity for England of making such a splendid reservoir. And as a friend to Egypt, I sigh still more that the country will not have such a splendid supply of water as would enable Upper Egypt to have the full benefits now possessed by Lower Egypt, and Lower Egypt to expand and fourish.
The reduced scheme will, however, be a great boon to the country, and I trust will now be put in hand without delay.

In 1884, when the expedition up the Nile was first being considered, I was asked by the General Officer commanding in Egypt, whether I thought there was any possibility of the Mahdi diverting the river in the Soudan, and depriving Egypt of its water. The late Sir Samuel Baker was in Cairo at the time, and I consulted him as to whether he knew of any place in the Nile valley where during hishest flood the water spills off to the right or left, towards the Red Sea or the Libyan Desert. He said he was sure there was no such place, and I then told the General it would be impossible for the Mahdi to divert the Nile. I was sure that with his savages he would never dam up the low supply until its surface attained the height of flood supply, and if even then during flood there was no spill channel, Egypt was safe enough.

But what the Mahdi could not do, a civilised penple could do. A Government official has no business to talk politics, and the Royal Institution is no place for politics; but I may be allowed to point out an evident enough fact, that the civilised possessor of the Upper Nile valley holds Egypt in his grasp.

At this moment the Italians are on the eastern edge of that valley - a nation, I must say, who have been consistently most friendly to us in Egypt. Supposing that they occupied Khartoum, the first thing they would naturally and very properly do would be to spread the waters of the Low Nile over the Soudan; and no nation in Europe understands irrigation so well. And what then would become of Egypt's cotton crops? They could only be secured by a series of the most costly dams over the river, and the fate of Philæ would surely be sealed. But more than this : a civilised nation on the Upper Nile would surely build regulating sluices across the outlet of the Victoria Nyanza, and control that great sea as Manchester controls Thirlemere. This would probably be an easy operation. Once done, the Nile supply would be in their hands; and if poor little Egypt had the bad luck to be at war with this people on the upper waters, they might flood them, or cut off their water supply at heir pleasure.

Is it not evident, then, that the Nile from the Victoria Nyanza to the Mediterranean should be under one rule? That time is perhaps far off. I conclude what I have to say tonight, by giving you the assurance, and I challenge contradiction, that at no time in the long history of Eyypt under Pharaoh or Ptolemy, Roman or Arab, or Turk, have the people of the country been so prosperous, or so justly ruled as during the last nine years.

\section{OBSERVATIONS OF SUN-SPOT SPECTRA. ${ }^{1}$ \\ I. The Widening of Iron Lines and of Unknown Lines in Relation to the Sun-spot Period.}

$\mathrm{T}$ is now twenty-eight years since $\mathrm{I}$ discovered that the lines seen in sun-spots were subject to widening, ${ }^{2}$ and that different lines were widened at different times.

It was not, however, till 1879 that I was enabled to commence daily routine work of such a nature that all observations were comparable inter se. This desideratum was secured by limiting attention to the twelve lines most widened between $F$ and $\mathrm{D}$.

In $1886^{3} \mathrm{I}$ gave an account of some of the early results obtained by this research. I have recently commenced the complete discussion of the whole series of observations to the present year.

This discussion, involving 21,000 lines widened during the period in question, has necessitated three special researches: the first, dealing with the lines with which, contemporaneously, coincidences have been found in the laboratory; the second, dealing with those the origin of which is so far unknown; and the third, with the distribution of both sets of lines in spots in relation to the sun-spot period.

To make the work as definite as possible, I am, in the first instance, confining the inquiry concerning the known lines to lines of iron based upon the examination of the pure electrolytic iron referred to in a previous communica tion.

I A Paper read at the Royal Society, by J. Norman Lackyer, C.B., F.R.S.

2 "Roy. Soc. Proc." vol. xv. p. 256, 1866.

3 "Roy. Soc. Proc." vol. xl. p. 347.
4 "Roy. Soc. Proc." vol. liv. p. 359. 